\title{
PARTILHANDO OLHARES SOBRE EDUCAÇÃO EM SUAS RELAÇÕES COM A FILOSOFIA
}

O gesto da partilha é um daqueles prezados pela RESAFE. Mais além da divulgação mera e simples das pesquisas, reflexões e experiências, nossa revista está ocupada em partilhar ideias, olhares, percepções e experiências que possam servir de esteio a interlocuções outras sobre as interfaces entre a filosofia e a educação.

Palavras, ideias e experiências que somam-se à vontade de investigar $e$ pensar sobre o que a filosofia tem a aprender com a educação, o que a educação tem a aprender com a filosofia, o que esses encontros podem potencializar, fazer ver e imaginar outras vivências educacionais, outras andanças filosóficas, expectativas sobre o ensino da filosofia e sobre a educação filosófica: esse é o contexto no qual nos colocamos na tarefa de fomentar a RESAFE como espaço de partilha.

Em seu número 25, a RESAFE mantém sua tradição de trazer uma pluralidade de abordagens sobre as interfaces entre filosofia e educação e, em especial, sobre o ensino da filosofia.

O texto de Cláudia Battestin, Gomercindo Ghiggi e Robinson dos Santos explora possibilidades educacionais das reflexões de Hans Jonas sobre a responsabilidade, enfatizando a dimensão ética do pensamento do estadunidense e relacionando com a educação.

O artigo de Ellen Maianne Santos Melo Ramalho e Walter Matias Lima explora as relações entre filosofia e autonomia, indicando que a presença da disciplina filosofia no currículo escolar é um potente exercício para o desenvolvimento da autonomia intelectual, uma vez que trabalha com habilidades críticas e criativas, que seriam bases desta autonomia.

As tensas relações entre os começos em filosofia e suas relações com as dificuldades sobre o aprender e o ensinar o filosofar são o tema do artigo de Ester Maria Dreher Heuser, que parte do referencial deleuziano e crítico da tradição moderna, para apostar na ideia do "impoder" como categoria para pensar o pensamento.

Fabio Barros Silva em seu artigo articula o problema da obediência, questão central para a filosofia política, na interpretação de Isaiah Berlin, às questões curriculares do ensino da filosofia, desde a experiência do estado de Minas Gerais.

Em um diálogo com Bergson e Deleuze, Janete Magalhães Carvalho e Steferson Zanoni Roseiro problematizam, por meio das redes de conversações em torno de imagens de filmes, os conceitos de tempo vivido, percebido e afetivo,

FLOR DO NASCIMENTO, wanderson. Partilhando olhares sobre a educação em suas relações com a filosofia. Revista Sul-Americana de Filosofia e Educação. Número 25: nov/2015 - abril/2016, p. 1-3. 
tendo os conceitos deleuzianos de imagem-tempo $e$ imagem-movimento como apontamentos para a potencialização do uso de filmes no contexto escolar.

Lisiane Costa Claro e Vilmar Alves Pereira, em seu artigo, abordam a postura fenomenológica como agregadora nas pesquisas educacionais, nos apresentando um encaminhamento articulado de fundamentos epistemológicos a partir das reflexões husserlianas aproximadas do contexto investigativo em educação pela autora e autor.

Uma abordagem inclusiva da educação especial é abordada pelo texto de Luciano da Silva Façanha e Wilma Cristina Bernardo Fahd, que partem das categorias sobre defectologia elaboradas por Vygotski, em sua proposta de se afastar das abordagens negativas e reducionistas das "deficiências" e sugerindo uma convivência entre estudantes diversos na escola.

$\mathrm{O}$ artigo de Luka de Carvalho Gusmão, a partir da leitura de alguns textos de Henri Bergson busca nas ideias de intuição e duração elementos que possam ser projetados na educação, sobretudo em função de gestos de respeito às diferenças.

A autonomia é novamente abordada, em sua dimensão ética, pelo artigo de Marcos Fábio A. Nicolau que, partindo de leituras de Paulo Freire, supõe a necessidade da ética como pressuposto para a tarefa docente e, também, o próprio ensino da ética. Nesse contexto, o reconhecimento da alteridade seria um caminho para o trabalho docente baseado na ética.

María José Guzmán e Cláudio Pinto Nunes discutem em seu texto as tensas relações sobre o saber sobre alteridade em suas complexas relações com a diferença através de diálogos com autores como Clastres, Foucault e Rancière, estabelecendo, assim, um horizonte para discutir educação, política e hierarquias de maneira a sugerir possibilidades críticas a posições de sujeição.

Uma abordagem da estratégia de uso do Diário de Bordo, como método cartográfico é o tema do texto de Maristela Barenco C. de Mello, que reflete sobre o trabalho com esse instrumental de modo estético e autoral, buscando uma epistemologia dos nexos que possibilite contextos de aprendizados marcados pela experiência e pelo cenário interdisciplinar.

Milena Quiroz aborda a problemática da presença e da cotidianidade na escola, a partir de memórias da infância, buscando problematizar o próprio espaço escolar em função de sua possibilidade de abrir-se ao estar e à presença que acolha a historicidade dos sujeitos que por ele passem.

O niilismo e seus impactos na educação é o tema do texto de Silmara Cristiane Pinto, que revisa a história do conceito e parte de Nietzsche para ler os desdobramentos do niilismo no contexto moderno, sobretudo, no que diz respeito à educação.

$\mathrm{O}$ artigo de Vanderlei Carbonara nos convida a pensar acerca da formação do licenciado em filosofia em função da problemática da experiência 
filosófica vivenciada, em tese, no processo de formação, ressaltando as dimensões da atitude filosófica, do papel da tradição filosófica e da elaboração conceitual.

$\mathrm{O}$ relato de experiência deste número da RESAFE é escrito por Elenilde Viegas e Tiago Ribeiro, que nos narram o projeto "Lá vem história", que articula a autoria, a leitura literária e a infância em uma escola pública do município do Rio de Janeiro.

Esperamos que esse conjunto de perspectivas, de olhares, componham cenários a partir dos quais possamos articular outros modos de ver e pensar as relações entre educação e filosofia, que possam ser críticos, criativos, solidários, belos...

Boa leitura!

wanderson flor do nascimento co-editor 